\title{
Pharmacognostic Evaluation of Leaf and Stem Wood Extracts of Artocarpus hirsutus Lam.
}

\author{
Mahadeva Nayak ${ }^{1}$, Ananthanarayanan Nagarajan ${ }^{1 *}$, Muhammed Majeed $^{1,2}$
}

\section{Mahadeva Nayak', Ananthanarayanan Nagarajan ${ }^{1 *}$, Muhammed Majeed ${ }^{1,2}$ \\ 'Sami Labs Limited-R\&D Center, 19/1, 19/2, 1st Main, 2nd Phase, Peenya Industrial Area, Peenya, Banga- lore-560058, karnataka, INDIA. ${ }^{2}$ Sabinsa Corporation, 20-Lake Drive, East Windsor, NJ-08520, USA. \\ Correspondence}

Ananthanarayanan Nagarajan

Sami Labs Limited- R\&D Centre, 19/1, 19/2, 1st Main, 2nd Phase, Peenya Industrial Area, Peenya, Bangalore, karnataka, INDIA.

Phone no: +91 8028397973

E-mail: nagarajan@samilabs.com; mahadevnayak@samilabs.com History

- Submission Date: 25-05-2017;

- Review completed: 28-07-2017;

- Accepted Date: 05-09-2017

DOI : 10.5530/pj.2017.6.139

Article Available online http://www.phcogj.com/v9/i6

\section{Copyright}

(c) 2017 Phcog.Net. This is an openaccess article distributed under the terms of the Creative Commons Attribution 4.0 International license.

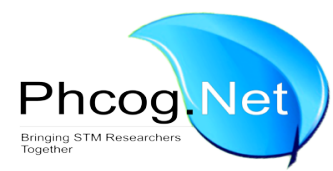

\begin{abstract}
Introduction: Artocarpus hirsutus Lam., a plant known for its fruits, used as a traditional medicine to treat skin diseases including hydrocele, pimple, heal sores, cracks in the skin. Pharmacological studies on the bark, root, leaf and fruit extracts of this species support their significance as antioxidants, as well as their efficacy on diuretic, antibacterial, anti-fungal and antiulcer activity. Methods: The present study focused on microscopic study, phytochemical analysis, HPLC and HPTLC finger print evaluation of leaf and stem wood extracts. Results: Microscopic analysis demonstrates its characteristic parameters namely hairy trichomes, pearl glands, vascular bundles, epidermis and is expected to assist easy identification of the genus. Conclusion: The solvent system, chloroform:methanol (8:2) was found to be the best as TLC eluent to visualize all major components of this species. HPLC and HPTLC finger prints not only confirm the presence of two major components, oxyresveratrol and artocarpin in stem wood extract, but also prove their absence in the leaf extract.
\end{abstract}

Key words: Artocarpus hirsutus Lam., Microscopy, Phytochemical analysis, HPTLC finger prints, HPLC.

\section{INTRODUCTION}

The genus Artocarpus belongs to family Moraceae and consists of more than 50 species. The species are either evergreen or deciduous trees, found in India, southern China, Malaysia and the Solomon Islands. Fruits of specific Artocarpus species are edible such as jack fruit and bread fruit, whereas other species of this genus (notably, A. heterophyllus Lam., A. altilis (Parkinson) Fosberg, A. hirsutus Lam., A. lakoocha Roxb. and A. camansi) usually find broad application as traditional medicines for treating diseases like diabetes, diarrhoea, dermatitis, malarial fever, asthma, tapeworm infection and anaemia. ${ }^{1}$ Studies on leaf extracts of $A$. lakoocha Roxb. clearly demonstrate its ability in protection against liver damage, lowering elevated blood pressure and managing the blood sugar. ${ }^{2}$ Major components in the bark, leaves and heart woods of the genus Artocarpus were found to be flavonoids with isoprene side chains ${ }^{3-6}$ possessing antioxidant, anti-inflammatory, anti-diabetic, tyrosinase and melanin inhibition properties. ${ }^{3,6-9}$

A. hirsutus commonly known as wild jack, is mainly distributed in South Western Ghats of Peninsular India. ${ }^{10}$ Like other species of the genus Artocarpus, A. hirsutus also acquires similar plant biographies. Notably, it's leaves are used traditionally in treating burboes and hydrocele whereas the leaves, fruits and barks help to cure diarrhoea, skin disease and haemorrhage. ${ }^{11}$ The paste of bark ash in coconut oil is used for Tinea curas (dhobi's itch). Topical application of stem bark infusion is found to be effective in heal- ing sores, cracks and pimples, ${ }^{1}$ whereas the fruit juice of $A$. hirsutus induces appetite and relives the pains of haemorrhage. ${ }^{10}$ Studies on pylorus ligated rats demonstrates that the A. hirsutus stem bark extract reduces the gastric secretory volume, acidity and ulceration. ${ }^{12}$

Nutritional natural supplements are often superior to synthetic supplements as they have minimal adverse effects, even in use for longer period. However, despite the benefits, there is still a relatively low commercial demand for these supplements. This could be due to non-availability of authentic raw material; inferior quality of raw material supply as well as lack of reproducible analytical techniques on herbal research. ${ }^{13}$ These technical complications can be resolved by conducting pharmacognostic studies of the raw material, which includes organoleptic characters, macroscopic analysis, microscopic analysis and powder study, physicochemical analysis, phytochemical analysis, HPLC and HPTLC finger print analysis. ${ }^{14}$

Marker compounds of natural origin are mostly used for confirming the correct botanical identity of the respective starting material. It is difficult to identify the correct marker compound for all traditional medicines because of the presence of unidentified multiple active constituents. By using chromatographic fingerprints, the authentication and identification of herbal medicines can be accurately achieved even if 
Nayak et al:: Pharmacognostic evaluation of Artocarpus hirsutus Lam.

the amount and/or concentration of the components are not same in different plant extracts. Consequently, the lack of reliable chromatographic fingerprints in the literature demonstrates the need to develop authentic techniques to reproduce pharmacologically active and chemically characteristic component of the herbal medicine.

The genus Artocarpus has been monographed by Jarrett. ${ }^{15}$ However, no pharmacognostic study has been reported on A. hirsustus except its stem bark by Dibinlal and Seethadevi. ${ }^{12}$ The present study is thus designed and executed in order to incorporate microscopic, phytochemical, HPLC and HPTLC finger print analysis of leaf and stem wood of $A$. hirsutus as an additional source of analytical techniques on this species.

\section{MATERIALS AND METHODS}

\section{General experimental procedures}

HPTLC finger printing studies were performed on CAMAG LINOMAT 5 using pre-coated TLC plates $[10 \times 10 \mathrm{~cm}$, silica gel 60 F254 TLC plates (Merck, India)]. The images were captured by using photo-documentation chamber (CAMAG REPROSTAR 3). The HPLC analysis was performed with Shimadzu Lab Solution HPLC system using LC-20AD software. Morphological evaluation was carried out using Nikon eclipse $\mathrm{Ci}$ microscope and the photographic images were captured by using a digital Nikon camera DS-Ri 2 fixed with the microscope.

\section{Collection of plant materials}

Fresh matured leaves and stem wood (Figure 1A and 1B) were collected from Udupi district, Karnataka, India, by the author in January 2015 and authenticated by Dr. M.D. Rajanna (Professor, Botanical Garden, University of Agriculture Sciences, GKVK, Bangalore, India). The voucher specimens were deposited in the departmental herbarium and assigned the voucher numbers (RD/HU-AH/10 and 12).

\section{Morphology}

Fresh samples of leaf and stem wood were preserved in formalin-acetic acid-alcohol (40\% formalin: $5 \mathrm{~mL}$ : 50\% ethanol: $90 \mathrm{~mL}$; glacial acetic acid: $5 \mathrm{~mL}$ ). Transverse sections were taken by using razor blade and were stained with Toluidine Blue O $0.05 \%$ in benzoate buffer $(0.25 \mathrm{~g}$ of benzoic acid in $200 \mathrm{~mL}$ water $\mathrm{pH} 4.4),{ }^{16}$ washed with water, observed under bright field as well as the epifluorescence optics using Nikon eclipse $\mathrm{Ci}$ microscope and the photographic images were captured using a digital Nikon camera DS-Ri 2 fixed with the microscope. The images were processed on Image NIS elements BR.

\section{Preparation of plant extract}

The fresh leaves and stem wood materials were dried and pulverized to a coarse powder. The powdered materials were individually extracted with three volumes of ethanol at refluxing condition $\left(65-70^{\circ} \mathrm{C}\right)$ for three times. The ethanolic extracts were dried completely under vacuum and subjected to phytochemical analysis, high performance liquid chromatography (HPLC) and high performance thin layer chromatography (HPTLC) finger print analysis to identify the chemical nature of the secondary constituents present in it.

\section{Phytochemical analysis}

The preliminary phytochemical screening for sterols, triterpenoids, alkaloids, flavonoids, lactones, tannins, saponins and carbohydrates were carried out as described by Evans. ${ }^{17}$

\section{HPTLC fingerprinting analysis}

HPTLC finger printing studies were performed following the methods of Wagner and Baldt, ${ }^{18}$ and Harborne. ${ }^{19}$ Various concentrations of both leaf and stem wood extracts $(1,2.5,5,10$ and $20 \mathrm{mg} / \mathrm{mL})$ were prepared in HPLC grade methanol (SD Fine chemicals, India) filtered through Whatman filter paper No. 1 and were used as test solutions for HPTLC analysis. The test solutions $(2.0 \mu \mathrm{L}$ each $)$ were then loaded on pre-coated TLC plates $\left[10 \mathrm{x} 10 \mathrm{~cm}\right.$, silica gel $60 \mathrm{~F}_{254}$ TLC plates (Merck, India) with aluminium sheet support] with band length of $6 \mathrm{~mm}$ using a CAMAG LINOMAT 5 Automatic Sample Spotter (Camag Muttenz, Switzerland) in duplicate. Similarly, another TLC plate $(5 \times 10 \mathrm{~cm})$ was loaded with $2.0 \mu \mathrm{L}$ each of ethanolic stem wood extract (concentration: $20 \mathrm{mg} / \mathrm{mL}$ ), leaf extract $(20 \mathrm{mg} / \mathrm{mL})$, oxyresveratrol $(1 \mathrm{mg} / \mathrm{mL})$ and artocarpin $(1 \mathrm{mg} /$ $\mathrm{mL}$ ). All loaded TLC plates were placed in twin trough glass chamber saturated with mobile phase (chloroform: methanol, 8:2) for 20 minutes and eluted to a distance of $9 \mathrm{~cm}$. The developed plate was positioned in the photo-documentation chamber (CAMAG REPROSTAR 3) and images were captured at 254 and $366 \mathrm{~nm}$. Furthermore, these plates were scanned at $200-400 \mathrm{~nm}$ by using HPTLC Scanner 3. To visualize the spots, the developed plates were exposed to iodine vapours as well as sprayed with vanillin sulphuric acid reagent followed by drying at 100 ${ }^{\circ} \mathrm{C}$ in hot air oven for 10 minutes. The images of vanillin sulphuric acid reagent treated plates were recorded in daylight and at $366 \mathrm{~nm}$.

\section{HPLC analysis}

The HPLC analysis were performed with Shimadzu, LC-20AD, prominence using a BDS Hypersil C18 (Thermo), 250 x $4.6 \mathrm{~cm}, 5 \mu \mathrm{M}$ column and mobile phase A: $0.05 \%$ acetic acid in water; B: $100 \%$ acetonitrile. The gradient program is depicted in box 1 .

\section{Box 1. Gradient program}

\begin{tabular}{cc}
\hline Time & B (concentration \%) \\
\hline 0.01 & 10 \\
20 & 100 \\
25 & 100 \\
30 & 10 \\
40 & 10 \\
\hline
\end{tabular}

Total flow rate: $1.0 \mathrm{~mL} / \mathrm{min}$; detector: PDA at $254 \mathrm{~nm}$; injection volume: $20 \mu \mathrm{L}$; run time: $30 \mathrm{~min}$; diluent: methanol (HPLC grade)

Sample solutions: Dissolved $100 \mathrm{mg}$ each of the ethanolic leaf and stem wood extracts with $25 \mathrm{~mL}$ of diluents in $50 \mathrm{~mL}$ volumetric flasks. After sonication for 15 minutes the volume was adjusted up to $50 \mathrm{~mL}$ with diluent and then filtered through Whatman No. 42 (ash less, diameter 125 mm, Cat. No. 1442-125).

Standard solutions: oxyresveratrol and artocarpin solutions were prepared with diluents at concentration of $0.1 \mathrm{mg} / \mathrm{mL}$.

\section{RESULTS AND DISCUSSION}

\section{Microscopic Characters}

Leaf

Leaf lamina is dorsiventral and the upper epidermis is mucilaginous. A few hairy trichomes are present near the midrib region. Occasionally, the outer cuticle envelope is interrupted by hydathode openings. The mesophyll cells are entirely of palisade parenchyma (2-4 cells thick) type and filled with numerous chloroplasts. It forms a complete network of cells with several secretory glands, called pearl glands, which is a significant feature of the leaf lamina surrounded by narrow bridges that contains vascular bundles. The upper epidermis is single layer thickness consisting of cystoliths here and there with calcified cell walls. The hairy trichome present in the lower epidermis consists of solitary prismatic calcium carbonate crystals at its base. The midrib contains 8-10 vascular 

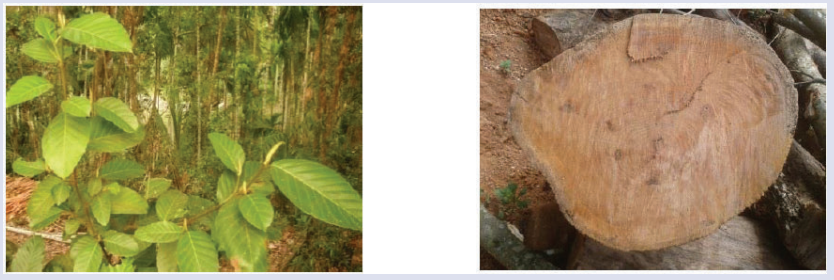

Figure 1A: Habit of A. hirsutus Lam. 1B: Cross cut of the stem wood of A. hirsutus Lam
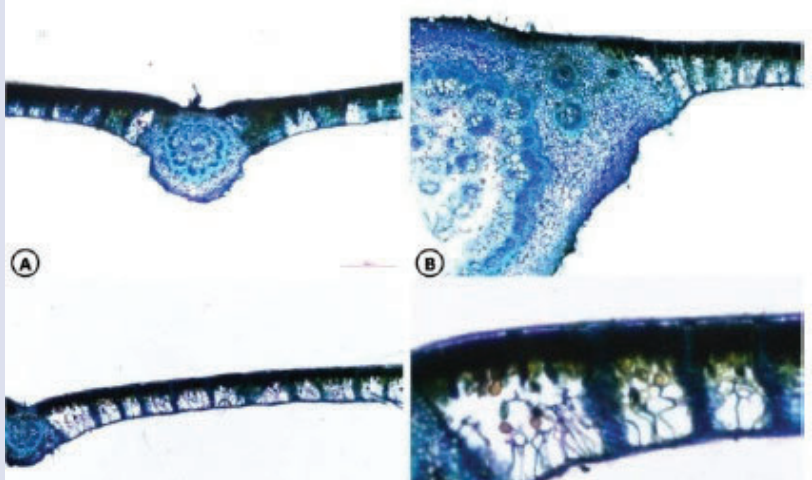

(c)
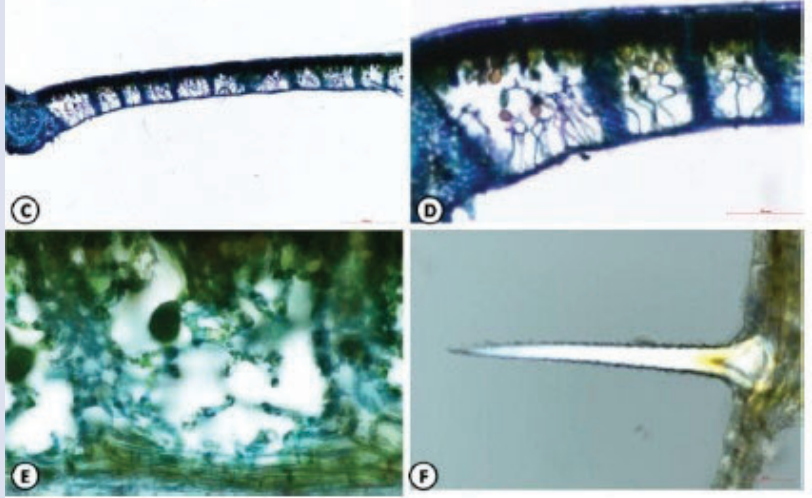

Figure 2: Transverse section of Leaf of $A$. hirsutus A. The entire view of leaf stained with TBO (4x); B. Transverse section of leaf viewed under 10x enlarged view of midrib; $C$. Transverse section of leaf blade; D. Enlarged view of leaf blade viewed under 10x; E. Transverse section shows the complete network of cells with secretory cells; F. Presence of trichome in the lower epidermis layer of leaf blade.

bundles. Vascular bundle is amphicribral type i.e. xylem surrounded by phloem. A sclerenchymatous cap surrounds bundle on the upper epidermal side (Figures 2A-F and 3A-D).

\section{Stem Wood}

The stem wood is brown to light black in colour, diffuse-porous, with solitary pores (occasionally grouped with two or three) and distinct growth rings. Tylose formation occurs in vessels in the matured wood. Vessel elements are simple perforation plates. Intervessel pits are alternate. The medullary rays are 2-3 cells thick. Ray cells are procumbent with one row of upright or squared marginal cells, axial parenchyma cells are paratracheal (Figure 4A-B).

\section{Phytochemical analysis}

The preliminary phytochemical analysis (Table 1) of extracts of leaf and stem wood revealed that the presence of sterols, terpenoids, flavonoids,
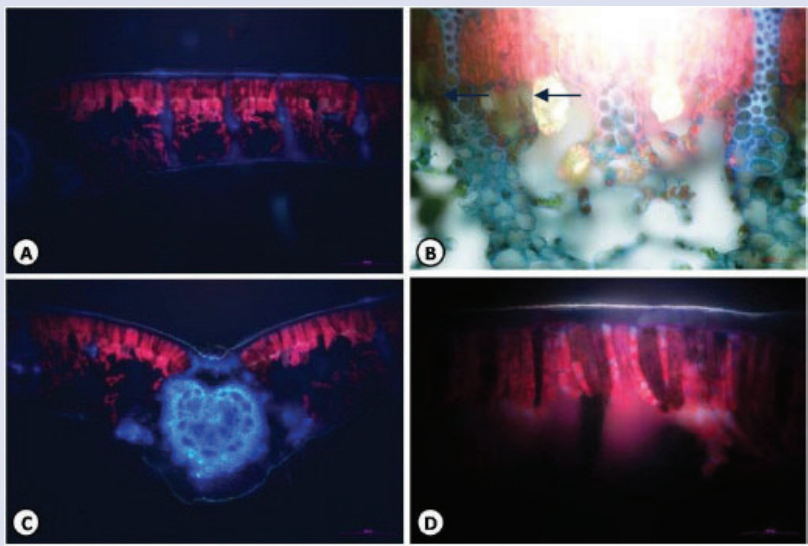

Figure 3: Transverse section of the leaf viewed under UV. A. Leaf blade reflects the blue and red colour resembling the lignified cell wall and vascular bundles (blue) and chloroplast filled palisade parenchyma cells (red); B. Enlarged view of chemical content present in the leaf (arrowed); C. Midrib region fully lignified; D. Palisade parenchyma cells shows the presence of chloroplast and the leaf blade covered with the thin layered cuticle.

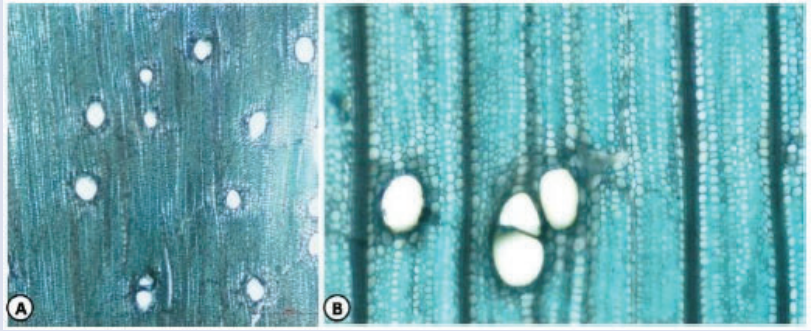

Figure 4: Transverse section of stem wood of $A$. hirsutus A. Stem wood stained with TBO; $\mathrm{B}$. A portion enlarged showing the vessel element, axial parenchyma cells, medullary rays.

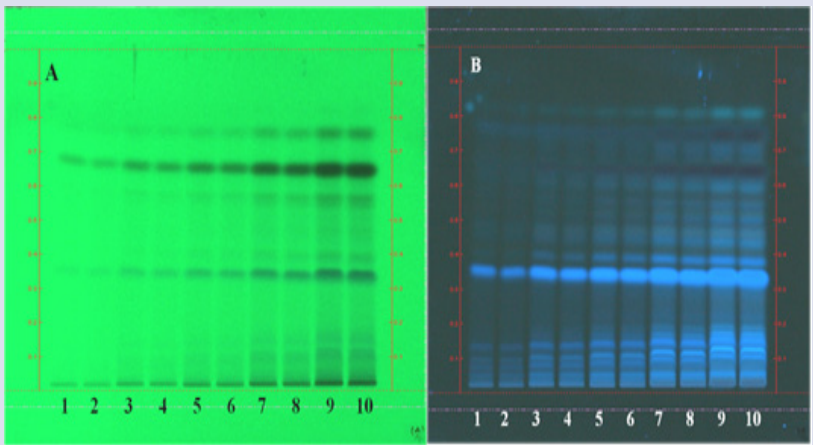

Figure 5: HPTLC photo documentation of ethanolic extract of wood of A. hirsutus: A. at $254 \mathrm{~nm}$ and B. at $366 \mathrm{~nm}$ light. Where, Tracks 1 and 2: $1 \mathrm{mg} / \mathrm{mL}$, Tracks 3 and 4: $2.5 \mathrm{mg} / \mathrm{mL}$, Tracks 5 and $6: 5 \mathrm{mg} / \mathrm{mL}$, Tracks 7 and 8: $10 \mathrm{mg} / \mathrm{mL}$, Tracks 9 and 10: $20 \mathrm{mg} / \mathrm{mL}$. 
Nayak et al:: Pharmacognostic evaluation of Artocarpus hirsutus Lam.

Table 1: Phytochemical studies of extracts of $A$. hirsutus

\begin{tabular}{|c|c|c|c|c|}
\hline SI. No. & Phytochemicals & Test Name & $\begin{array}{c}\text { Ethanolic extract } \\
\text { of Leaf }\end{array}$ & $\begin{array}{l}\text { Ethanolic extract of } \\
\text { stem wood }\end{array}$ \\
\hline \multirow[t]{2}{*}{1} & Sterols & a. Salkowaski test & + & + \\
\hline & & b. LB test & + & + \\
\hline \multirow[t]{2}{*}{2} & Triterpenoids & a. Salkowaski test & + & + \\
\hline & & b. LB test & + & + \\
\hline \multirow[t]{4}{*}{3} & Alkaloids & a. Mayers test & - & - \\
\hline & & b. Dragendorff test & - & - \\
\hline & & c. Wagners test & - & - \\
\hline & & d. Hagers test & - & - \\
\hline \multirow[t]{3}{*}{4} & Flavonoids & a. Shinoda test & + & + \\
\hline & & b. ferric chloride test & + & + \\
\hline & & c. lead acetate test & + & + \\
\hline \multirow[t]{3}{*}{5} & Lactones & a. Baljet test & + & + \\
\hline & & b. Legal test & + & + \\
\hline & & c. Fiegels test & + & + \\
\hline \multirow[t]{2}{*}{6} & Tannins & a. Ferric chloride test & + & + \\
\hline & & b. Gelatin test & + & + \\
\hline 7 & Saponins & a. Foam test & + & + \\
\hline \multirow[t]{2}{*}{8} & Carbohydrates & a. Molisch's test & - & + \\
\hline & & b. Benedict's test & - & + \\
\hline
\end{tabular}

Where, “+”: Positive and “-”: Negative

Table 2: $\mathbf{R}_{\mathrm{f}}$ values of ethanolic extracts of $\boldsymbol{A}$. hirsutus

\begin{tabular}{|c|c|c|c|c|c|}
\hline \multirow{3}{*}{ Sample } & \multicolumn{5}{|c|}{ Visualization ( $R_{f}$ values) } \\
\hline & \multirow{2}{*}{ @ 254 nm } & \multirow{2}{*}{ @ 366 nm } & \multirow{2}{*}{$\begin{array}{c}\text { lodine vaporisation - White } \\
\text { light }\end{array}$} & \multicolumn{2}{|c|}{ Vanillin - sulphuric acid treatment } \\
\hline & & & & White light & @ 366 nm \\
\hline $\begin{array}{l}\text { Stem wood } \\
\text { extract }\end{array}$ & $\begin{array}{c}0.1,0.35,0.4 \\
0.55,0.65,0.75\end{array}$ & $\begin{array}{c}0.1,0.12,0.35,0.38,0.42,0.5 \\
0.6,0.65,0.7,0.75,0.82\end{array}$ & $0.1,0.15,0.35,0.38,0.65,0.75$ & $0.1,0.15,0.35,0.65,0.75$ & $0.1,0.15,0.35,0.55,0.65,0.75$ \\
\hline Leaf extract & $0.28,0.58,0.65$ & $0.28,0.3,0.6,0.65,0.82,0.88$ & $0.1,0.28,0.5,0.65$ & $0.55,0.6,0.82,0.88$ & $\begin{array}{c}0.1,0.2,0.25,0.4,0.58,0.6,0.75 \\
0.82,0.88\end{array}$ \\
\hline
\end{tabular}

tannins and saponins. Vinay et $a l,{ }^{20}$ reported the presence of alkaloids, flavonoids, saponins and terpenoids in A. hirsutus fruit whereas similar results described by Lakshmi et al, ${ }^{21}$ in root. Azeem et al, ${ }^{22}$ demonstrated the presence of flavanoids, glycosides, saponins, carbohydrates, proteins and amino acids, tannins and alkaloids in ripped fruits.

HPTLC profile

HPTLC finger prints were developed for extracts in various solvent systems with changing polarities to verify the chemical constituents present. Our study revealed that the solvent system, chloroform:methanol $(8: 2)$ was superior among the other combinations for both leaf and stem wood extracts. The HPTLC images, as shown in figures 5, 6, 7 and 8, indicate the clear separation of constituents of both extracts. The $R_{f}$ values are tabulated in table 2 .

HPTLC of stem wood extract

HPTLC of ethanolic extract of stem wood illustrated 7 compounds when observed under $254 \mathrm{~nm}$ light (Figure $5 \mathrm{~A}$ ). The spot having $\mathrm{R}_{\mathrm{f}}$ at 0.60 was found to be the major component, which was navy blue in colour. When the same TLC plate was monitored under UV light at $366 \mathrm{~nm}$ (Figure $5 B), 13$ compounds were noted. Of these, the spot with $R_{f}$ at 0.30 was found to be major component, which appeared as bluish fluorescent in

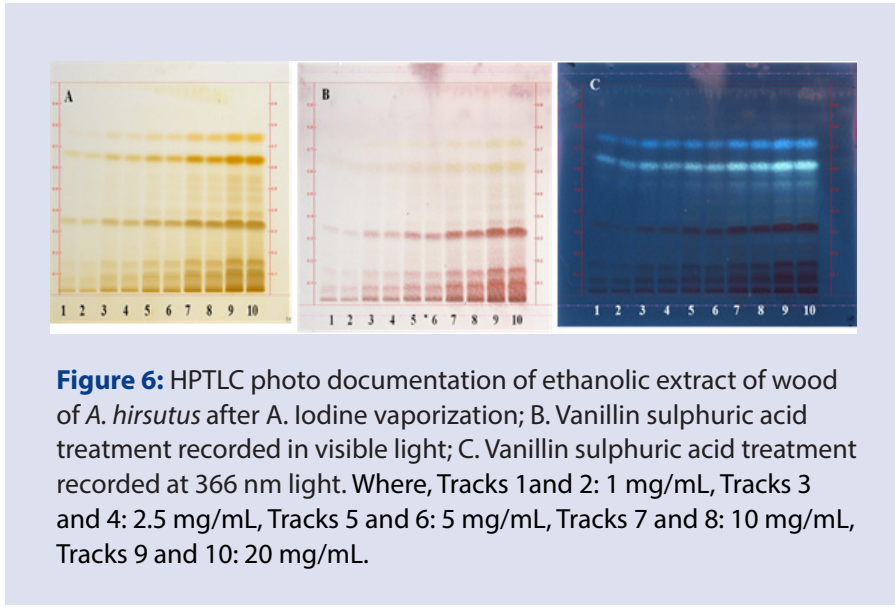



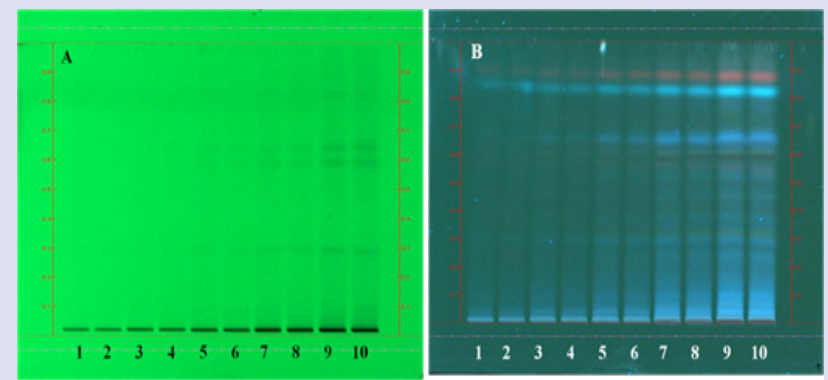

Figure 7: HPTLC photo documentation of ethanolic extracts of leaf of A. hirsutus A. at $254 \mathrm{~nm}$ and B. at $366 \mathrm{~nm}$ Light. Where, Track 1 and 2: $1 \mathrm{mg} / \mathrm{mL}$, Track 3 and 4: $2.5 \mathrm{mg} / \mathrm{mL}$, Track 5 and $6: 5 \mathrm{mg} / \mathrm{mL}$, Track 7 and 8: $10 \mathrm{mg} / \mathrm{mL}$, Track 9 and 10: $20 \mathrm{mg} / \mathrm{mL}$.
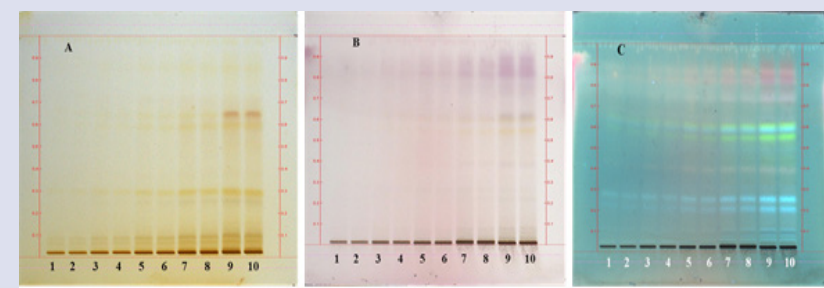

Figure 8: HPTLC photo documentation of ethanolic extracts of leaf of A. hirsutus after A. lodine vaporization; B. Vanillin sulphuric acid treatment recorded in visible light; $C$. Vanillin sulphuric acid treatment recorded at $366 \mathrm{~nm}$ light. Where, Tracks 1and 2: $1 \mathrm{mg} / \mathrm{mL}$, Tracks 3 and 4: $2.5 \mathrm{mg} / \mathrm{mL}$, Tracks 5 and 6: $5 \mathrm{mg} / \mathrm{mL}$, Tracks 7 and $8: 10 \mathrm{mg} / \mathrm{mL}$, Tracks 9 and 10: $20 \mathrm{mg} / \mathrm{mL}$.

colour. The intensity of the major compound at $254 \mathrm{~nm}$ was reduced when it was observed at $366 \mathrm{~nm}$.

There were 6 compounds with yellow to yellowish brown colour when the TLC plate was exposed to iodine vapours (Figure 6A). Both compounds with $R_{f} 0.30$ and $R_{f} 0.60$ were found to be major components.

When the TLC plate was treated with vanillin sulphuric acid and heated at $100{ }^{\circ} \mathrm{C}$ for 10 minutes, 6 compounds were detected at day light (Figure $6 B)$. The spots with $R_{f}$ below 0.30 showed pink colour whereas $R_{f}$ at 0.60 and $R_{f}$ at 0.73 were yellow in colour. The spot with $R_{f}$ at 0.30 was found to be major compound. Interestingly when the same TLC plate was visualized under $366 \mathrm{~nm}$ (Figure 6C), the spots of $R_{f}$ of 0.60 and $R_{f}$ of 0.73 were illuminated with pale yellow and blue fluorescence respectively. The spots at $R_{f}$ of 0.30 and $R_{f}$ of 0.60 were found to be major compounds.

\section{HPTLC of leaf extract}

HPTLC finger print of ethanolic leaf extract displayed 4 spots (Figure $7 \mathrm{~A}$ ) with $\mathrm{R}_{\mathrm{f}}$ at $0.28,0.58,0.63$ and 0.82 when the TLC plate was analysed at $254 \mathrm{~nm}$ and the intensities of all spots were low. There were 8 spots observed when the TLC plate was visualized at $366 \mathrm{~nm}$ (Figure 7B). The spot having $R_{f}$ at 0.80 was found to be a major component at $366 \mathrm{~nm}$, which was blue fluorescent in colour. The spot with $R_{f}$ at 0.88 when visualized in $366 \mathrm{~nm}$ was pink in colour and expected to be a triterpenoid. ${ }^{18}$

Five spots with yellow to yellowish brown colour were identified when the TLC plate was exposed to iodine vapours (Figure 8A). The intensity of the compound with $\mathrm{R}_{\mathrm{f}}$ at 0.65 was highest compared to the other

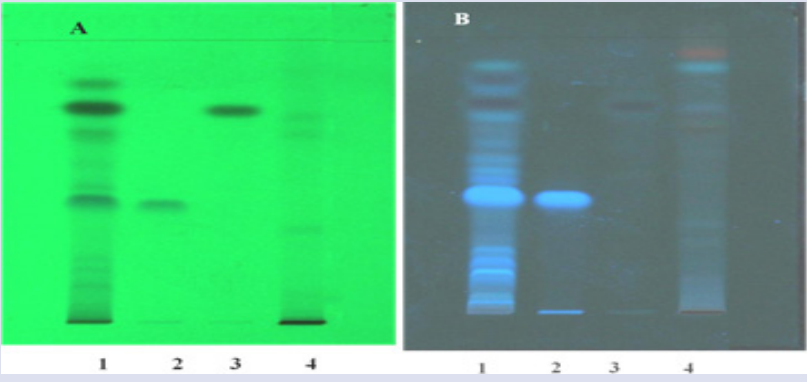

Figure 9: HPTLC photo documentation of ethanolic extracts of leaf and stem wood of $A$. hirsutus along with oxyresveratrol and artocarpin after A. at $254 \mathrm{~nm}$; B. at $366 \mathrm{~nm}$ light. Where, Track 1:20 mg/mL stem wood extract; Track 2: Oxyresveratrol (1 mg/mL); Track 3: Artocarpin $(1 \mathrm{mg} / \mathrm{mL})$; Track4: $20 \mathrm{mg} / \mathrm{mL}$ leaf extract.
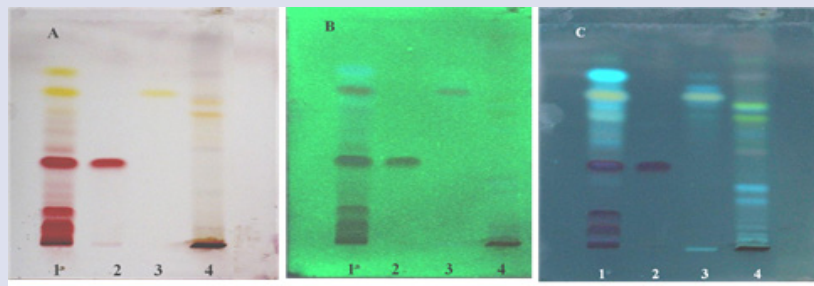

Figure 10: HPTLC photo documentation of ethanolic extracts of leaf and stem wood of $A$. hirsutus along with oxyresveratrol and artocarpin after A. Vanillin sulphuric acid treatment recorded at visible light; B. Vanillin sulphuric acid treatment recorded at $254 \mathrm{~nm}$ light; C. Vanillin sulphuric acid treatment recorded at $366 \mathrm{~nm}$ light. Where, Track 1: $20 \mathrm{mg} / \mathrm{mL}$ stem wood extract; Track 2: Oxyresveratrol $(1 \mathrm{mg} / \mathrm{mL})$; Track 3: Artocarpin (1mg/mL); Track 4: $20 \mathrm{mg} / \mathrm{mL}$ leaf extract.

compounds present in the extract. The intensity of the major compound $\left(\mathrm{R}_{\mathrm{f}} 0.80\right)$ at $366 \mathrm{~nm}$ was diminished, similarly it was observed that on exposure to iodine vapours, it's yellow colour disappears. When the TLC plate was treated with vanillin sulphuric acid and heated at $100{ }^{\circ} \mathrm{C}$ for 10 minutes, 5 spots were identified at day light (Figure 8B). The spot above $\mathrm{R}_{\mathrm{f}}$ at 0.80 appeared as pink in colour with maximum intensity. Interestingly when the same TLC plate was visualized under $366 \mathrm{~nm}$ (Figure $8 \mathrm{C})$, more than 10 spots with different colour intensities were detected. The spots having $\mathrm{R}_{\mathrm{f}}$ at 0.18 and $\mathrm{R}_{\mathrm{f}}$ at 0.23 were bluish fluorescent in colour. The spots with $\mathrm{R}_{\mathrm{f}}$ at 0.55 and $\mathrm{R}_{\mathrm{f}}$ at 0.60 were yellow and greenish yellow in colour respectively. The spots at $R_{f}$ of 0.80 and $R_{f}$ of 0.85 were pink in colour. The intensities of all these spots were same and could be isolated individually.

\section{Comparison of HPTLC finger prints with standard compounds}

Further the HPTLC finger prints (Figures 9A, 9B, 10A, 10B and 10C) of both stem wood and leaf extracts $(20 \mathrm{mg} / \mathrm{mL})$ were compared with two standard materials notably oxyresveratrol ${ }^{23}$ and artocarpin..$^{24}$ Oxyresveratrol is a stilbene derivative and found in species of the same genus, viz. A. lakoocha Roxb.; A. champlasha Roxb.; A. heterophyllus Lam.; A. gomezianus Wall. $(7,24-26)$.

Oxyresveratrol spot was illuminated with bluish fluorescence at $366 \mathrm{~nm}$ with $R_{f}$ at 0.30 (Figure 9B) and this spot was appeared as pink in colour when the TLC plate was sprayed with vanillin sulphuric acid and heated 


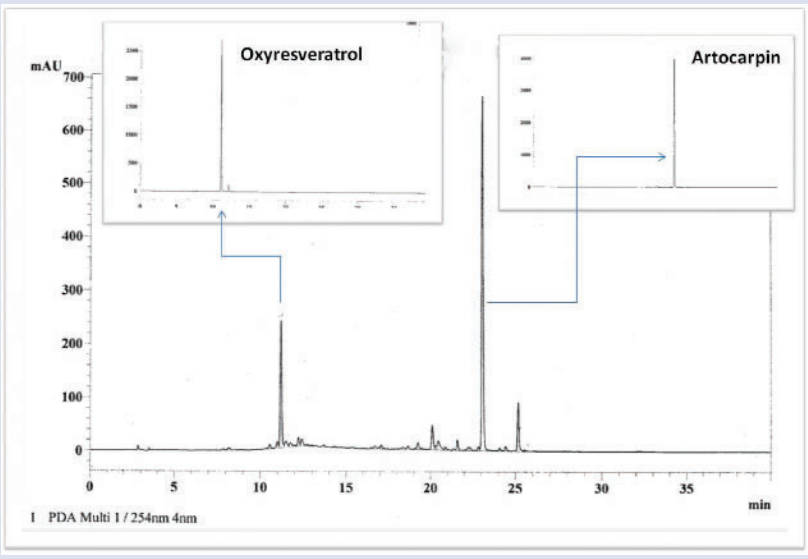

Figure 11: HPLC chromatogram of ethanolic extract of stem wood $A$. hirsutus.

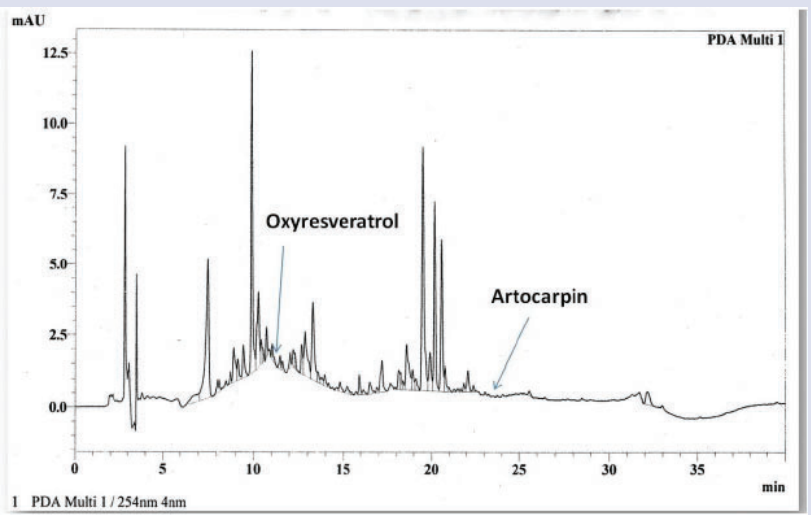

Figure 12: HPLC chromatogram of ethanolic extract of leaf $A$. hirsutus.

at $100{ }^{\circ} \mathrm{C}$ for 10 minutes (Figure $10 \mathrm{~A} ; 27$ ) whereas it was detected as purple in colour when it was visualized at $366 \mathrm{~nm}$ (Figure 10C). Artocarpin is a flavonoid and reported to be found in species of the same genus mainly A. heterophyllus, A. incises, A. nitidus and A. hirsutus. ${ }^{24,28-30}$ The HPTLC of artocarpin displayed as dark spot at $254 \mathrm{~nm}$ (Figure 9A) and navy blue spot at $366 \mathrm{~nm}$ (Figure 9B). The compound also appeared as yellow spot with vanillin sulphuric acid reagent when detected at visible light and at $366 \mathrm{~nm}$ (Figure 10A, 10C).

HPTLC finger print of ethanolic stem wood extract showed the presence of both oxyresveratrol as well as artocarpin as the major compounds. Whereas appearances of these compounds were absent in HPTLC finger prints of ethanolic leaf extract. The constituents of stem wood and the leaves were totally different and cannot be interchanged. Hence it is essential to isolate the actives from the leaf extract and explore their pharmacological benefits. Recently, it was reported by us that oxyresveratrol isolated from wood of $A$. hirsutus possessed promising antiinflammatory, antioxidant and skin lightening properties. ${ }^{23}$

\section{HPLC analysis}

HPLC chromatogram of stem wood extract (Figure 11) represented the presence of 4 major peaks, with retention time (RT) at $11.206(17.928 \%)$,
20.114 (4.001\%), $23.092(52.368 \%)$ and 25.180 (7.001\%) minutes. Of these, the peak eluted at $23.092 \mathrm{~min}$ was found to be the major component and contains more than half of the total weight. The second highest peak was found with RT at $11.206 \mathrm{~min}$. These two peaks corresponds with artocarpin (RT $23.040 \mathrm{~min}$ ) and oxyresveratrol (RT, $11.004 \mathrm{~min}$ ) respectively.

The HPLC chromatogram of leaf extract (Figure 12) showed the presence of 5 peaks with retention time (RT) at $7.533(10.849 \%), 9.910(11.874 \%)$, $19.544(52.368 \%) 20.197$ and 20.592 (7.001\%). However, the corresponding peaks for oxyresveratrol and artocarpin were not detected in the HPLC chromatogram. It further reconfirms with the HPTLC results and represents the absence of oxyresveratrol and artocarpin in the leaf extract.

\section{CONCLUSION}

Present study describes the micromorphology, phytochemical analysis, HPLC and HPTLC finger print analysis of the leaf and stem wood which are in use as the traditional medicine. Determination of cell structural organisation and analysis of the tissues system are some of the pharmacognostic properties that are important for identifying the correct species of the plant and for distinguishing between closely related species of the same genus. The leaf shows the distinct network of mesophyll cells with the pearl glands and the palaside parenchyma cells possessing 2 to 4 cells thick with several chloroplasts. The axial parenchyma cells of stem wood are paratracheal and vessels are filled with tylose and vessels elements show the pits with simple perforation plates.

The preliminary phytochemical analysis of ethanolic extracts of leaf and stem wood of $A$. hirsutus showed that the presence of various secondary metabolites like sterols, terpenoids, flavonoids, lactones, tannins and saponins. The mobile phase, chloroform: methanol (8:2) was found to be superior solvent system for HPTLC and the plates were displayed with maximum separation of the components having distinct $\mathrm{R}_{\mathrm{f}}$ values. This solvent system can be used during the isolation of constituents from both extracts. HPTLC finger prints of stem wood extract demonstrated the presence of oxyresveratrol and artocarpin, whereas they were absent in leaf extract and it was further confirmed by HPLC analysis. Hence the stem wood extract cannot be replaced with leaf extract for commercial purpose.

In conclusion, the micromorphological parameters, HPLC and HPTLC finger prints presented in this report can be used as diagnostic tools for the correct identification of the raw material of similar species, as well as to distinguish the admixture of known/or unknown material and to check the quality of the raw material. Both oxyresveratrol and artocarpin could be used as reference compounds for standardization of the stem wood extract of $A$. hirsutus.

\section{ACKNOWLEDGEMENT}

The author(s) thank to Dr. Ambar K. Choudhury, Dr. M. Kathiresh, Mr. Manoj Kumar Yadhav, Mr. Kiran Kumar Vuppala, Mr. John Adams, Analytical R\&D team of Sami Labs Limited for their valuable support.

\section{CONFLICTS OF INTEREST}

The authors disclose no conflict of interest.

\section{ABBREVIATIONS}

HPLC: High Performance Liquid Chromatography; HPTLC: High Performance Thin Layer Chromatography; TLC: Thin Layer Chromatography; PDA: Photo Diode Array; mL: Mili Litre; min: minute; nm: nano meter; No.: Number; LB Test: Liebermann-Burchard test; RT: Retention Time. 


\section{REFERENCES}

1. Asha DS, Ben CP. Least concerned bark and stipules of Artocarpus species (Moraceae) - an effective antibacterial agent. Int Res J Biological Sci. 2014;3(2):25-9

2. Jagtap UB, Bapat VA. Artocarpus: A review of its traditional uses, phytochemistry and pharmacology. Journal of Ethanopharmacology. 2010;129(2):142-66.

3. Panthong K, Tohdee K, Hutadilok TN, Voravuthikunchai SP, Chusri S. Prenylated flavone from roots of a hybrid between Artocarpus heterophyllus and Artocar pus integer and its biological activities. J Braz Chem Soc. 2013;24(10):1656-61.

4. Sritularak B, Tantrakarnsakul K, Likhitwitayawuid K, Lipipun V. New 2-Arylbenzofurans from the root bark of Artocarpus lakoocha. Molecules. 2010;15:6548-58

5. Wei BL, Weng JR, Chiu PH, Hung CF, Wang JP et al. Anti-inflammatory flavonoids from Artocarpus heterophyllus and Artocarpus communis. J Agric Food Chem. 2005;53:3867-71.

6. Zheng ZP, Chen S, Wang S, Wang XC, Cheng KW, Wu JJ et al. Chemical components and tyrosinase inhibitors from the twigs of Artocarpus heterophyllus. J Agric Food Chem. 2009;57(15):6649-55

7. Fang SC, Hsu CL, Yen GC. Anti-inflammatory effects of phenolic compounds isolated from the fruits of Artocarpus heterophyllus. J Agric Food Chem. 2008;56:4463-8

8. Rao GV, Mukhopadhyay T, Radhakrishnan N. Artoindinesianin F, a potent tyrosinase inhibitor from the roots of Artocarpus heterophyllys Lam. I. J Chem. 2010;49B(9):1264-6

9. Sireesha K, Raghunandan N. Evaluation of in vivo antidiabetic and antioxidant activity of Artocarpus hirsutus seeds in streptozotocin-induced diabetic rats. Asian J Pharm Clin Res. 2016;9(1):170-3.

10. Hari A, Revikumar KG, Divya D. Artocarpus: A review of its phytochemistry and pharmacology. Journal of Pharma Search. 2014;9(1):7-12.

11. Plant of the Month - Artocarpus hirsutus. Available at http://frlhtenvis.nic.in/KidsCentre/Artocarpus_hirsutus_1636.aspx. Accessed July 26, 2016

12. Dibinlal D, Sathish SD, Senthil Kumar KL. Pharmacognostical studies on the bark of Artocarpus hirsutus Lam. Hygeia J D Med. 2010;2:22-7.

13. Om P, Jyoti Kumar A, Kumar P, Manna NK. Adulteration and substitution in Indian Medicinal Plants: an overview. Journal of Medicinal Plants Studies. 2013;1(4):127-32.

14. Chandra S. Importance of pharmacognostic study of medicinal plants: An overview. J Pharmacogn Phytochem. 2014;2(5):69-73.

15. Jarret FM. Studies in Artocarpus and allied genera, I. A revision of Artocarpus subgenus Artocarpus. Journal of the Arnold Arboretum. 1959;40:1-29.

16. Krishnamurthy KV. Methods in plant histochemistry. S. Vishwanathan printers and publishers, Madras (1987)
17. Evans WC and Trease GE. Pharmacognosy. $15^{\text {th }}$ ed. London: Saunders Publishers; 42-44. 221-229, 246-249, 304-306, 331-332, 391-393.

18. Wagner H, Baldt S. Plant Drug Analysis. A Thin Layer Chromatography Atlas, $2^{\text {nd }}$ ed. Springer, Berlin, Germany (1996).

19. Harborne JB. Phytochemical Methods, $3^{\text {rd }}$ Ed. Chapman and Hall, London, UK (1998).

20. Vinay SMN, Venkatachalapathy R, Makari HK, Ramesh BS. Phytochemical analysis and antimicrobial activity of Artocarpus hirsutus: an in vitro study. Int $\mathrm{J}$ Pharm Bio Sci. 2014;5(3):98-104.

21. Lakshmi P, Ganapaty S, Mary BK. Phytochemical and biological examination of the root extract of Artocarpus hirsuta, Lam. International Journal of Bioassays. 2013;2(4):735-8

22. Azeem AK, Rasheed A, Dilip C, Junise V, Rani S. Diuretic activity of the fruits of Artocarpus hirsutus Lam. J C S. 2013;1:16-9.

23. Nayak M, Nagarajan A, Majeed M. Evaluation of in vitro antioxidant potential anti-inflammatory activity and melanogenesis inhibition of Artocarpus hirsutus Lam. extracts. I J S T R. 2017;6(1):196-203.

24. Venkataraman K. Wood phenolics in the chemotaxonomy of the Moraceae Phytochemistry. 1972;11:1571-86.

25. Povichit N, Phrutivorapongkul A, Suttajit M, Leelapornpisid P. Antiglycation and antioxidant activities of oxyresveratrol extracted from the heartwood of Artocar pus lakoocha Roxb. Maejo Int J Sci Technol. 2010;4(3):454-61.

26. Likhitwitayawuid K, Sornsute A, Sritularak B, Ploypradith P. Chemical transformations of oxyresveratrol (trans-2,4,3',5'-tetrahydroxystilbene) into a potent tyrosinase inhibitor and a strong cytotoxic agent. Bioorg Med Chem Lett. 2006;16(21):5650-3.

27. Palanuvej $C$, Issaravanich $S$, Tunsaringkar T, Rungsiyothin A, Vipunngeun $N$, Ruangrungsi N, Likhitwitayawuid K. Pharmacognostic study of Artocarpus lakoocha heartwood. J Health Res. 2007;21(4):257-62.

28. Le TPH, Nguyen HH. Tyrosinase inhibitors from the heartwood of Vietnamese Artocarpus heterophyllus. J Nat Prod Plant Resour. 2015;5(4):1-4

29. Itsarasook K, Ingkaninan K, Viyoch J. Artocarpin-enriched extract reverses collagen metabolism in UV-exposed fibroblasts. J Biologia. 2014;69(7):943-51.

30. Lin L, Ti H, Liu M, Wei X. Chemical constituents from stems of Artocarpus nitidus subsp. lingnanensis. Journal of Tropical and Subtropical Botany. 2012;20(5):529-32.

\section{GRAPHICAL ABSTRACT}

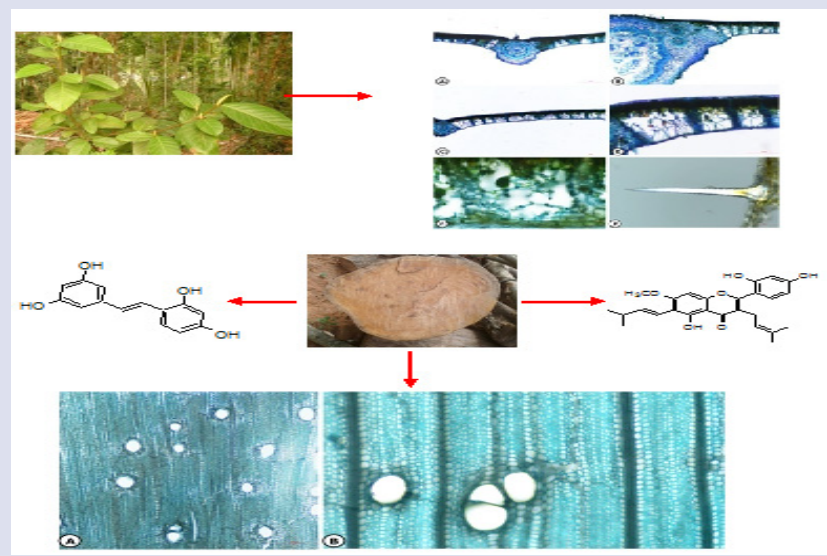

\section{SUMMARY}

- Present study describes the micromorphology, phytochemical analysis, HPLC and HPTLC finger print analysis of the leaf and stem wood of $A$. hirsutus.

- The leaf shows the distinct network of mesophyll cells with the pearl glands and the palaside parenchyma cells possessing 2 to 4 cells thick with several chloroplasts. The axial parenchyma cells of stem wood are paratracheal and vessels are filled with tylose and vessels elements show the pits with simple perforation plates.

- The mobile phase, chloroform: methanol (8:2) is found to be superior solvent system for HPTLC.

- HPTLC finger prints of stem wood extract demonstrates the presence of oxyresveratrol and artocarpin, whereas both are absent in leaf extract that is further confirmed by HPLC analysis. 


\section{ABOUT AUTHORS}

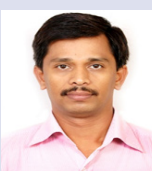

Mr. Mahadeva Nayak, Research scholar, has been with Sami Labs Limited since 2002 in R\&D centre as a Scientist and since 2008 he holds the position of Manager - Technical Marketing, which primarily works as an interface between R\&D, Product and Business Development. He obtained his Graduation degree in Pharmacy from College of Pharmaceutical Sciences, Manipal, affiliated to Mangalore University and Masters degree in Pharmacy (M. Pharm) from Government College of Pharmacy, Bangalore, affiliated to Rajiv Gandhi University of Health Sciences, Bangalore. He has published more than 5 articles in reputed journals and co-author in 2 books.

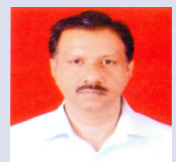

Dr. Ananthanarayanan Nagarajan is the Vice president R\&D of Sami Labs and associated with the company for the last 22 years. His research interests are in synthetic methodology, chiral and natural products. He obtained his Ph.D in Organic Chemistry from the University of Madras. He has three years post doctoral research experience at the University of Oklahoma, USA in the area of organometallic and organic chemistry. Having more than 30 years of research experience in the field of Organic Chemistry, he has published more than 15 articles in reputed journals.

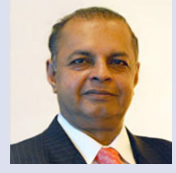

Dr. Muhammed Majeed, pursued his MS (Long Island University) \& Ph.D in Industrial Pharmacy at St. John's University, New York. After working in Pfizer (R\&D Divisions), Carter Wallace and Paco Research as Head of R\&D, New Jersey, USA, Dr. Majeed has established his own Industry, Sabinsa/Sami Group of Companies in the year 1988 in USA and India. He is Founder \& Managing Director/CEO since then. For his outstanding contributions to the community, he was awarded by the US Congress in 2005 with Ellis Island Medal of Honour. He has published 150 papers in reputed journals, inventor of more than 160 patents and published 15 books.

Cite this article: Nayak M, Nagarajan A, Majeed M. Pharmacognostic Evaluation of Leaf and Stem Wood Extracts of Artocarpus hirsutus Lam. Pharmacog J. 2017;9(6):887-94. 